\title{
Peranan Pendidikan Kewarganegaraan (PKn) Dalam Pembentukan Moral Peserta Didik
}

\author{
Yuliana Syamsul, Rohmad Widodo, Agus Tinus \\ FKIP Universitas Muhammadiyah Malang, Indonesia \\ Email : andyoel_chumi@yahoo.com
}

\begin{abstract}
Moral is somebody's act/attitude/speech in interacting with others. If what is conducted by somebody suitable with value in society and can be accepted also please the surrounding, he/she is regarded as having good moral. By using SMK Muhmmadiyah 2 Malang as the object, the researcher conducts a study on "The role of civics (PKn) in building students' moral in SMK Muhammadiyah 2 Malang".This study is aimed to know the problems on the focus of study; they are: (1) How is the role of civics in building students' moral in SMK Muhammadiyah 2 Malang? (2) What obstacles faced in building students' moral in SMK Muhammadiyah 2 Malang? (3) What are the solutions to overcome the obstacles in building students' moral in SMK Muhammadiyah 2 Malang? This study used qualitative approach. To obtain the data, the researcher used observation, interview and documentation. Meanwhile, for checking data validity, the researcher used credibility, transferability, dependability and confirmability.From the result of study, it is obtained that the role of civics in building students' moral in SMK Muhammadiyah 2 Malang is by embedding responsibility, caring, discipline and nationality also teach students on religious. Yet, in building students' moral, there are obstacles such as the less of parents' attention and comprehension and society so that children often do something which harms them. To overcome the obstacles, the teachers are expected that there is still good cooperation between teacher, parent and society.
\end{abstract}

Keywords: the role of civics; moral building; students

\section{PENDAHULUAN}

Merebaknya isu-isu moral di kalangan remaja seperti tawuran pelajar, merusak barang milik orang lain, perampasan, penipuan, penganiayaan dan lain-lain sudah menjadi masalah sosial yang sampai saat ini belum dapat diatasi secara tuntas. Akibat yang ditimbulkan cukup serius dan tidak dapat lagi dianggap sebagai suatu persoalan sederhana, karena tindakan-tindakan tersebut sudah menjurus pada tindakan kriminal. Kondisi ini sangat memprihatinkan masyarakat khususnya para orang tua dan Guru (Pendidik), sebab pelaku-pelaku beserta korbannya adalah kaum remaja terutama para pelajar dan mahasiswa.

Banyak orang berpandangan bahwa kondisi demikian diduga bermula dari apa yang dihasilkan oleh dunia pendidikan. Pendidikan yang sesungguhnya paling besar memberikan kontribusi terhadap situasi ini. Mereka yang telah melewati sistem pendidikan selama ini, mulai dari pendidikan dalam keluarga, lingkungan sekitar, dan sekolah, kurang memiliki kemampuan mengelola konflik dan kekacauan, sehingga anak-anak dan remaja selalu menjadi korban konflik dan kekacauan tersebut.

Melihat kondisi banyaknya penyimpangan moral dikalangan anakanak dan remaja saat ini, menjadikan tugas yang diemban oleh para Guru /Pendidik dan perancang dibidang Pendidikan moral sangat rumit. Demi mencerdaskan kehidupan Bangsa dan melestarikan budaya, suatu pendidikan harus berupaya menyeluruh untuk menyelenggarakan semua jenis pendidikan. Jenis pendidikan yang salah satunyauntuk membentuk Bangsa yaitu melalui pendidikan kewarganegaraan (PKn). PKn berkontribusi dalam sebuah pembangunan sebuah Bangsa. Kontribusi nyata PKn dalam sebuah Pendidikan 
dengan adanya mata pelajaran tersebut.

Adapun sebuah bangsa bisa berkembang dan maju dengan adanya sebuah pembangunan struktural dalam diri setiap individu melalui perkembangan moral, moral menjadi sebuah hal penting yang akan berkontribusi dalam perkembangan sebuah bangsa, karena bangsa yang beridentitas akan diakui oleh Negara lain. Menurut Muliani Kualitas Pendidikan di Indonesia saat ini sangat memprihatinkan. Gambaran ini tercermin dari beragamnya masalah pendidikan yang semakin rumit. Kualitas siswa masih rendah, pengajar kurang profesional, rendahnya kualitas sarana fisik serta biaya pendidikan yang mahal (Budiningsih, 2004:1-3).

Siswa sering bolos sekolah, berani menentang guru dan bersikap seenaknya di sekolah. Bagaimana bisa terwujud sistem belajar mengajar yang kondusif dan komprehensif? Bagaimana mereka bisa memperoleh pendidikan yang bermutu? Menurut Kusrahmadi Pendidikan bertujuan bukan hanya membentuk manusia yang cerdas otaknya dan terampil dalam melaksanakan tugas, namun diharapkan menghasilkan manusia yang memiliki moral, sehingga menghasilkan warga negara yang lebih baik. Walaupun gurunya profesional bila moral siswa rendah, maka mutu pendidikan juga sama rendahnya. Oleh karena itu, fokus utama yang harus diperbaiki untuk meningkatkan mutu Pendidikan Indonesia saat ini adalah meningkatkan moralitas siswa dengan memberikan Pendidikan moral sehingga ada keterpaduan sistem pembelajaran baik dari sarana, biaya, pengajar dan pelajar. Tujuan Pendidikan moral tidak semata-mata menyiapkan peserta didik untuk menelan mentah konsep-konsep pendidikan moral, tetapi yang lebih penting adalah terbentuknya karakter yang baik, yaitu pribadi yang memiliki pengetahuan moral, peranan perasaan moral dan perilaku moral
(Lickona, 1992. P. 53).

Dewasa ini, pelaksanaan pendidikan moral di sekolah diberikan melalui Pendidikan Kewarganegaraan (PKn) dan Pendidikan Agama, akan tetapi tampaknya lebih berorientasi pada penguasaan materi yang tercantum dalam kurikulum atau buku, dan kurang mengaitkan dengan karakter pribadi siswa sehingga tidak menumbuhkan kepribadian siswa yang baik. Siswa mendapatkan pendidikan moral hanya masuk telinga kanan keluar telinga kiri, tidak diterapkan pada sikap dan kepribadian siswa.

Pendidikan moral sangatlah perlu bagi manusia, karena melalui pendidikan perkembangan moral diharapkan mampu berjalan dengan baik, serasi dan sesuai dengan norma demi harkat dan martabat manusia itu sendiri. Di Indonesia Pendidikan moral telah ada dalam setiap jenjang pendidikan. Di Sekolah Dasar perkembangan Pendidikan moral tak pernah beranjak dari nilai-nilai luhur yang ada dalam tatanan moral Bangsa Indonesia yang termasuk jelas dalam Pancasila sebagai Dasar Negara. Pendidikan Moral Pancasila, yang sejak dari Pendidikan dasar telah diajarkan tentu memiliki tujuan yang sangat mulia, tiada lain untuk membentuk anak negeri sebagai individu yang beragama, memiliki rasa kemanusiaan, tenggang rasa demi persatuan, menjunjung tinggi nilai-nilai musyawarah untuk kerakyatan serta berkeadilan hakiki.

SMK Muhammadiyah 2 Malang merupakan salah satu Sekolah Menengah Kejuruan yang ada di Malang, dimana ada beberapa Jurusan yang diambil oleh peserta didik sehingga membuat peserta didik hanya akan fokus pada kompetensi keahliannya yang menyebabkan peserta didik mempunyai karakter yang berbeda. Dengan berbagai karakter tersebut maka timbul permasalahan seperti tawuran antar pelajar, kurangnya sikap kedisplinan dalam diri siswa dimana siswa cenderung rame dan bicara sendiri ketika proses KBM 
berlangsung, dan sebagainya. Namun pelanggaran terbesar yang sering terjadi pada peserta didik di SMK Muhammadiyah 2 Malang ini yaitu terletak pada siswa yang sering bolos pada jam pelajaran berlangsung, telat pada saat Upacara Pagi, merokok di lingkungan sekolah, membawa Hp dan sedikitnya ada beberapa siswa yang terlibat pergaulan bebas yang berimbas pada siswa sendiri yang akhirnya dikeluarkan dari sekolah.

\section{METODE}

Dalam penelitian kualitatif, penggunaan analisis isi lebih banyak ditekankan pada bagaimana simbol-simbol yang ada pada komunikasi itu terbaca dalam interaksi sosial, dan bagaimana simbolsimbolitu terbaca dan dianalisis oleh peneliti. Dan sebagaimana penelitian kualitatif lainnya, kredibilitas peneliti menjadi amat penting. Analisis isi memerlukan peneliti yang mampu menggunakan ketajaman analisisnya untuk merajut fenomena isi komunikasi menjadi fenomena sosial yang terbaca oleh orang pada umumnya.

Pada bagian ini peneliti perlu menjelaskan bahwa pendekatan yang digunakan adalah pendekatan kualitatif, dan menyertakan alasan-alasan singkat mengapa pendekatan ini digunakan. Selain itu juga dikemukakan orientasi teoritik, yaitu landasan berfikir untuk memahami makna suatu gejala, atau masalah moral yang terjadi pada SMK Muhammadiyah 2 Malang. Peneliti juga perlu mengemukakan jenis penelitian yang digunakan dalam penelitian ini.

Pendekatan kualitatif adalah suatu proses penelitian dan pemahaman yang berdasarkan pada metodologi yang menyelidiki suatu fenomena sosial dan masalah manusia. Pada pendekatan ini, peneliti membuat suatu gambaran kompleks, meneliti kata-kata, laporan terinci dari pandangan responden, dan melakukan studi pada situasi yang alami
(Creswell, 1998:15). Bogdan dan Taylor (dalam Moleong, 2007:3) mengemukakan bahwa metodologi kualitatif merupakan prosedur penelitian yang menghasilkan data deskriptif berupa kata-kata tertulis maupun lisan dari orang-orang dan perilaku yang diamati.

\section{HASIL DAN PEMBAHASAN}

Pendidikan moral bukanlah sebuah topik baru dalam pendidikan. Pada kenyataanya, pendidikan moral ternyata sudah seumur pendidikan itu sendiri. Berdasarkan penelitian sejarah dari seluruh negara yang ada didunia ini, pada dasarnya pendidikan memiliki dua tujuan yaitu membimbing para generasi muda untuk menjadi cerdas dan memilih perilaku berbudi.

Banyak sekali guru yang tidak berani mengambil sikap dalam bidang ini. Mereka takut terlalu mengambil bagian dalam urusan pribadi masing-masing orang. Mereka kawatir dengan aspek kewenangan hukum. Mungkinkah seseorang akan membawa mereka untuk berurusan dengan hukum jika ia tidak menyukai cara para guru memberikan pendidikan nilai moral.

Saat ini semakin banyak bukti yang menunjukan bahwa sekolah telah mampu membuat sebuah perubahan dalam pengembangan karakter anak. Pertanyaan yang kemudian muncul adalah sejauh mana peranan pendidikan dalam menanamkan nilai-nilai moral terhadap peserta didik. Melalui SMK Muhammadiyah 2 Malang peneliti melakukan pengumpulan data.

Setelah peneliti mengumpulkan data dari hasil penelitian dalam bentuk observasi, wawancara dan dokumentasi. Selanjutnya peneliti melakukan analisa data untuk menjelaskan lebih lanjut mengenai hasil penelitian yang telah dilakukan. Sesuai dengan teknik analisis data yang digunakan yaitu teknik analisis kualitatif, maka berikut data yang diperoleh dan akan dipaparkan oleh peneliti adalah Sebagai berikut: 
Peranan Pendidikan Kewarganegaraan (PKn) dalam pembentukan moral peserta didik di SMK Muhammadiyah 2 Malang Berdasarkan data yang diperoleh dari hasil wawancara dengan beberapa informan menganai peranan Pendidikan Kewarganegaraan dalam pembentukan moral peserta didik di SMK Muh. 2 Malang, yaitu dengan cara (1) Menanamkan pembiasaan sikap dan perilaku yang didasari oleh nilai agama dan moral sehingga anak dapat hidup sesuai dengan nilai-nilai yang dijunjung oleh masyarakat, seperti mengajarkan tentang sholat, sekilas memberikan kajian keislaman dan lain lain. (2) Membantu anak agar tumbuh menjadi pribadi yang matang dan mandiri yaitu dengan mengajarkan dan membiasakan peserta didik dengan berbuat baik seperti menghargai sesama, menolong temannya. (3) Melatih anak untuk dapat membedakan sikap dan perilaku yang baik dan yang tidak baik sehingga dengan sadar berusaha menghindarkan diri dari perbuatan tercela seperti tidak menggunakan kata-kata jorok disekolah. Penanaman nilai-nilai moral ini hampir sama dengan pendekatan yang dilakukan dalam (Adisusilo, 2012:191).

Selain itu guru PKn sendiri membentuk moral siswa dengan memberikan nasehatnasehat yang yang mengarahkan peserta didik ke hal-hal yang baik seperti ada kegiatan sholat berjama'ah, hafalan ayat suci Al-Qur'an. Sama halnya dengan pembinaan moral pada pada penelitian yang dilakukan oleh (Saedin, 2005:58) yaitu pembinaan beragama yang dilakukan kepada narapidana sesuai dengan agama dan kepercayaanya masing-masing, seperti halnya yang beragama islam yaitu dengan mendatangkan ustadz untuk memberikan ceramah.

Dibuktikan pula dengan hasil wawancara dengan beberapa siswa yang mengatakan bahwa salah-satu pembentukan moral di SMK Muh. 2 Malang yaitu dengan mengadakan sholat berjama'ah serta mengadakan kajian keislaman.
Kendala-kendala yang dihadapi dalam pembentukan moral peserta didik di SMK Muhammadiyah 2 Malang

Pembentukan moral anak merupakan tanggung jawab semua pihak seperti orang tua, lingkungan masyarakat dan sekolah. Namun yang menjadi kendala dalam pembentukan moral anak yatu terletak pada siswa sendiri yang malas mengikuti, lingkungan masyarakat dan orang tua, dimana lingkungan sangat berpengaruh terhadap perkembangan anak, karena apapun yang terjadi dan berlaku di dalam lingkungan masyarakat maka hal demikian yang dilakukan oleh anak, dan kendala terbesar juga terjadi didalam lingkungan keluarga dimana orang tua berlaku apatis dan tidak memperhatikan perkembangan anak.

Hal demikian terjadi pula pada hasil penelitian yang dilakukan oleh (Saedin, 2005:59) yaitu kendala narapidana yang malas mengikuti kegiatan-kegiatan pembinaan yang dilakukan oleh Lembaga Pemasyarakatan, serta kurangnya dukungan dari lingkungan masyarakat.

\section{Solusi yang diambil untuk mengatasi kendala-kendala dalam pembentukan moral peserta didik di SMK Muh. 2 Malang}

Menurut Mansoer (dalam Erwin, 2010:3) pada hakikatnya Pendidikan Kewarganegaraan itu merupakan hasil dari sintesis antara civic education, democracy education, serta citizenship yang berlandaskan pada filsafat pancasila serta mengandung identitas Nasional Indonesia serta materi muatan tentang bela Negara. Pendidikan Kewarganegaraan merupakan salah satu konsep Pendidikan yang berfungsi untuk membentuk siswa sebagai Warga Negara yang mempunyai karakter. Keterkaitan Pendidikan Kewarganegaraan terhadap pengembangan karakter memiliki dimensi-dimensi yang tidak bisa dilepaskan dari aspek pembentukan karakter dan 
moralitas publik warga Negara.

Dapat disimpulkan bahwa Pendidikan harus mampu memberikan solusi yang cepat dan tepat jika terjadi masalah degradasi moral pada peserta didik. Dari hasil penelitian yang diperolah dari beberapa informan di SMK Muhammadiyah 2 Malang mengenai solusi yang diberikan dengan adanya kendala-kendala dalam pembentukan moral peserta didik yaitu dengan cara pembelajaran tentang moralnya perlu dikembangkan lagi guna membentuk peserta didik yang benar-benar memiliki karakter dan moral yang baik.

\section{SIMPULAN}

Setiap mata pelajaran mempunyai peranannya masing-masing dalam pembentukan moral peserta didik, pembentukan moral tidak hanya dilakukan oleh mata pelajaran Agama, Sejarah dan Olah Raga saja. Namun demikian pula dengan Pendidikan Kewarganegaraan juga ikut serta berperan dalam pembentukan moral siswa. Pendidikan Kewarganegaraan mempunyai cara/strategi tersendiri dalam penanaman moral peserta didik yaitu dengan cara sebagai berikut: (a) Menanamkan pembiasaan sikap dan perilaku yang didasari oleh nilai agama dan moral sehingga anak dapat hidup sesuai dengan nilai-nilai yang dijunjung oleh masyarakat, seperti mengajarkan tentang sholat, sekilas memberikan kajian keislaman. (b) Membantu anak agar tumbuh menjadi pribadi yang matang dan mandiri yaitu dengan mengajarkan dan membiasakan peserta didik dengan berbuat baik seperti menghargai sesama, menolong temannya. (c) Melatih anak untuk dapat membedakan sikap dan perilaku yang baik dan yang tidak baik sehingga dengan sadar berusaha menghindarkan diri dari perbuatan tercela seperti tidak menggunakan kata-kata jorok disekolah.

Kendala dalam pembentukan moral peserta didik di SMK Muh. 2 Malang yaitu rata-rata terletak pada siswanya sendiri yang dimana terjadi banyak perbedaan dalam diri siswa itu sendiri seperti kalau dilihat dari backgroundnya yaitu dari sekolah muhammadiyah namun yang terjadi adalah peserta didiknya hanya $20 \%$ yang berasal dari muhammdiyah sehingga menjadi kendala terbesar di SMK Muhammadiyah 2 Malang, juga kendalanya terletak pada siswa yang orang tuanya sibuk bekerja sehingga kurang memperhatikan anaknya yang berimbas pada sikap dan tingkah lakunya di sekolah.

Solusi yang mungkin tepat untuk dilakukan di SMK Muhammadiyah 2 Malang yaitu dengan menggunakan metode nasehat dan hukuman seperti apa yang dilakukan oleh ibu Sri Wahayuniati selaku guru PKn SMK Muhammadiyah 2 Malang. Metode nasehat diberikan kepada keseluruhan siswa. Jika anak membuat kesalahan orang tua akan memberikan peringatan agar anak tidak salah menentukan sikap. Memang hal tersebut sering dan biasa dilakukan oleh guru-guru lainnya serta metode hukuman khusus diberikan kepada siswa yang mengalami masalah dengan tujuan siswa tidak melakukan kesalahan lagi. Dengan banyaknya kendala-kendala yang memang kurang terjalinnya hubungan baik antara siswa dengan siswa lain, siswa dengan orang tua maka perlu adanya kerja sama yang baik antara siswa, guru, orang tua serta lingkungan masyarakat agar tercipta pendidikan yang utuh.

Selanjutnya peneliti akan memberikan saran yang merupakan masukan bagi pembentukan moral peserta didik di SMK Muhammadiyah 2 Malang. Yang nantinya akan bermanfaat bagi peserta didik. Saran yang dapat diberikan adalah sebagai berikut: Mata pelajaran PKn sudah ikut serta berperan didalam pembentukan moral siswa, namun kalah jauh dengan Pendidikan Agama, untuk selanjutnya bisa ditingkatkan lagi pembelajaran moralnya serta untuk pelatihan sholat, kajian keislaman, dan lain lain dipertahankan agar tetap terciptanya 
peserta didik yang bermoral yang nantinya akan terjun ke dunia masyarakat. Melihat dari hasil penelitian terdapat beberapa kendala-kendala yang dihadapi dalam pembentukan moral peserta didik di SMK Muhammadiyah 2 Malang, maka dengan adanya kendala-kendala yang terjadi maka pembelajaran moralnya perlu diperketat lagi dengan banyak perbedaan yang muncul dari peserta didik yang bukan dari muhammadiyah perlu diberikan pemahaman khusus serta terus mengajak orang tua siswa dan lingkungan sekitar untuk bekerja sama dalam pembentukan moral peserta didik.

\section{DAFTAR PUSTAKA}

Adam, Pramudya. 2009. Peran Pendidikan Kewarganegaraan dalam Membentuk Moral Bangsa Indonesia . Yogyakarta: Yrama Widya

Adisusilo, Sutarjo J.R. 2012. Pembelajaran nilai-karakter "konstruktivisme dan VCT sebagai inovasi pendekatan pembelajaran afektif". Jakarta. PT RAJAGRAFINDO PERSADA

Agus Zaenul Afirin. 2012. Pendidikan karakter berbasis nilai dan etika disekolah. Jogjakarta. AR-RUZZ MEDIA.

Asf,Jasmani; Syaiful Mustofa. 2013. Supervise Pendidikan: Terobosan Baru dalam Kinerja Peningkatan Kerja Pengawas Sekolah dan Guru. Jogjakarta. Ar-Ruzz Media

Budiningsih, Asri. 2004. Pembelajaran moral "Berpijak pada Karakter siswa dan Budayanya”. Jakarta. Rineka Cipta

Chamim, Asyukuri ibn. 2003. Pendidikan kewarganegaraan. Jogjakarta. Majelis Pendidikan Tinggi.

Durkheim, Emile. 1990. Pendidikan Moral. Jakarta. Erlangga

Erwin, Muhammad. 2010. Pendidikan Kewarganegaraan Republik Indonesia. Bandung. PT Refika Aditama
Lickona, Thomas. 2012. Educating For Character "Mendidik Untuk Membentuk Karakter”. Jakarta. Bumi Askara

Margono S, 2007. Metodelogi penelitian pendidikan. Jakarta. PT. RINEKA CIPTA

Meleong, J Lexy. 2009. Metodelogi Penelitian Kualitatif. Bandung. Remaja Rosdakarya

Poerwanti, Endang. Nurwidodo. 2010. Perkembangan Peserta Didik. Malang. FKIP-UMM

Saifuddin, Lukman Hakim. 2012. "Pentingnya Pembentukan Karakter Bangsa” (Diakses dalam http://mpr. go.id pada tanggal 18 Januari 2014)

Silalahi, Ulber. 2009. Metode penelitian sosial. Bandung. PT refika Aditama

Solihatin, Etin. 2012. Strategi Pembelajaran $P P K N$. Jakarta. PT Bumi Askara

Takdir, Muhammad Ilahi. 2012 Revitalisasi Pendidikan Berbasis Moral. Jogjakarta. Ar-Ruzz Media

Zuriah, Nurul. 2006. Metodelogi penelitian "social dan pendidikan". Jakarta. PT Bumi Aksara

Ruslidan Qaderie.2013. Metode Penelitian Kuantitatif dan Kualitatif. Sumenep: LP3M "Paramadani" Prenduan.

Singodimayan, Hasnan. 2006. Ritual Adat Seblang Banyuwangi. Surabaya: Purbengkara 